\title{
IAMJ
}

INTERNATIONAL

AYURVEDIC MEDICAL JOURNAL

Review Article

ISSN: 23205091

Impact Factor: 5.344

\section{COMPARATIVE STUDY OF AVEDHYA SIRA AND SIRA MARMA WITH W.S.R. TO URVI SIRA IN UPPER EXTREMITY}

\author{
Pooja Thakur' ${ }^{1}$, Madhavi Goswami² \\ ${ }^{1}$ P.G. Scholar, Dept. of Rachana Sharir, Uttrakhand Ayurved University, Rishikul Campus, \\ Haridwar, Uttarakhand, India \\ ${ }^{2}$ H.O.D. Dept. of Rachana Sharir, Uttrakhand Ayurved University, Rishikul Campus - Haridwar, Utta- \\ rakhand, India
}

Email: drpoojathakur73@gmail.com

\section{https://doi.org/10.46607/iamjp04042020}

(Published online: May 2020)

Open Access

(C) International Ayurvedic Medical Journal, India 2020

Article Received: 09/05/2020 - Peer Reviewed: 17/05/2020 - Accepted for Publication: 17/05/2020

\section{Check for updates}

\section{ABSTRACT}

Acharya Sushruta described various surgeries meticulously. During the ancient time, Acharya Sushruta performed various major and minor surgeries with surprisingly great accuracy and thus was able to treat dreadful diseases. The proper knowledge of Sharira was essential to meet this high standard of accuracy. Especially, during performing any surgery or Sira Vedhan one must be aware of the vital points, Marma and the Avedhya Sira present in the body. This is because even a slight trauma to these may lead to severe complications such as severe pain, any deformity or even death of a person. There are 107 Marmas and 98 Avedhya Siras mentioned by Acharya Sushruta. Most of the name of Avedhya Sira are same as nomenclature of Marma. For example, Brihati is a name of Avedhya Sira and is also a Marma. Here an effort has been made to study the role of Marma Sthan in confirmations of Avedhya Sira with special reference to Urvi (Bahavi) Sira in upper extremity.

Keywords: Avedhya Sira, Marma, Urvi Sira

\section{INTRODUCTION}

Acharya Sushruta who is regarded as the father of surgery described various surgeries meticulously such as Asthibhanga (fracture of bones) Nasa
Sandhan (Rhinoplasty), Lingnash (cataract) etc. For performing these surgeries, he knows the importance of a through anatomical knowledge therefore he dis- 
sected many cadavers (Shavavichhedanam) and observed the structures in them. During performing any surgery or Sira Vedhan, one must be aware of the vital points, Marma and the Avedhya Sira present in the body.

The Marmas are the vital points of the body. A trauma to Marma may cause severe pain, deformity and death. These are the points containing life (Prana Sthana) where Marma, Sira,

Snayu, Asthi and Sandhi come together by nature. ${ }^{1}$ Total numbers of Marmas are 107 mentioned by Acharya Sushruta. ${ }^{2}$ A detailed description composing of the number of Marmas, their situations in the body, constitution, their Anguli Pramana as well as signs and symptoms when injured is well elaborated in the 'Pratyaksha Marma Nirdesha' Adhyaya of Sushruta Samhita.

Acharya Charak in Sutra Sthana described Sira as 'Saranat Sira'3 means the blood vessels in which Saran Kriya of blood takes place. Saran Kriyas denotes very slow flow of blood. Acharya Sushruta has mentioned 700 Siras $^{4}$ in the seventh Adhyaya i.e. Siravarnavibhaktishariropakrama. Acharya Sushruta keenly observed them, studied in detail and very systematically explained the importance and contraindications of a venipuncture. Out of these 700 Siras, 98 are Avedhya Sira in human body. The Siras which on Vedhan or puncture causes Vaikalya (deformity) or Maran (death) of a person are known as Avedhya Siras. ${ }^{5}$ Name of some of the Marmas of the body are same as the name of Avedhya Siras. These structures should be carefully protected while performing any surgical procedure to avoid any complications. Therefore, a study was carried out to evaluate the importance of Avedhya Sira and Marma in the present days and to create a relationship between two. Urvi (Bahavi) Marma in the upper extremity which acts as both the Avedhya Sira and Sira Marma was chosen for the study.

Materials and Methods- Material- Relevant textbooks of Ayurveda, their commentaries, modern science and cadaver for dissection.

Method- All the references regarding Avedhya Sira and Sira Marma were collected from the relevant textbooks of Ayurveda as well as modern anatomy. Dissection was carried out as per the guidelines given in Cunningham's manual of dissection. Accordingly, dissection was done, and conclusion was drawn.

Urvi (Bahavi) Marma- It is located in the middle of thigh. In case of upper limb, the Marma point can be considered as the middle of the arm. ${ }^{6}$

Classification-

- Sira Marma ${ }^{7}$

- Vaikalyakara Marma ${ }^{8}$

- Bahu Marma. ${ }^{9}$

- 1 Angula ${ }^{10}$

- 12 angul Praman ${ }^{11}$

- 2 in number (one in each arm) Effect of injury-

Injury to this Sira marma leads to loss of blood and emaciation of the limb. ${ }^{12}$

Arunadatta commenting on this occasion specifies that as the emaciation of the limb will occur, Siravyadha is prohibited.

Urvi (Bahvi Sira)- The word meaning of Urvi is the wide one, the two wide ones. ${ }^{13}$

Acharya Susruta explains that there are two Siras named Urvi which are not to be punctured. ${ }^{14}$ Dalhanacharya commenting on the Urvi Sira states that these Siras are located in the region of Urvi marma. Even though two Urvi Siras are mentioned, Acharya Susruta had mentioned only one Marma in name Urvi.

Dalhanacharya explains that it is because of the closeness of the Siras in the location of the Mar$m a$, the Marma is explained as one even though there are two Siras.

Dalhanacharya also mentioned that the Marmas located in arm should be named according to the location. So Urvi Marma in hand refers to Bahvi Marma. $^{15}$

According to Dr. Bhaskar Govind Ghanekar, Urvi Sira (Bahavi) in upper extremity can be considered as brachial vessels. ${ }^{16}$

Brachial Artery- It is a continuation of the axillary artery, begins at the distal (inferior) border of the tendon of teres major and ends about a centimeter distal 
to the elbow joint (at the level of neck of the radius) by dividing into radial and ulnar arteries. At first it is medial to the humerus, but gradually spirals anterior to it until it lies midway between the humeral epicondyles. Its pulsation can be felt throughout. Branches of the brachial artery are profunda brachii, nutrient, superior, middle and inferior ulnar collateral, deltoid, muscular, radial and ulnar arteries.

The profunda brachy is a large branch from the posteromedial aspect of the brachial artery, distal to the teres major. It follows the radial nerve closely, at first posteriorly between the long and medial heads of triceps, then in the spiral groove covered by the lateral head of triceps. ${ }^{17}$

Brachial Veins- The brachial veins flank the brachial artery, as venae comitantes with tributaries similar to the arterial branches; near the lower margin of subscapularis they join the axillary vein. The medial branch, however, often joins the basilic before it becomes the axillary. These deep veins have numerous anastomoses with each other and with the superficial veins. $^{18}$

\section{Applied Anatomy-}

The brachial artery pulsation is important and regular clinical practice as this is the most common artery used for measurement of blood pressure. The pulsation of brachial artery can be felt or auscultated in front of the elbow just medial to the tendon of biceps while recording blood pressure. Although the artery can be compressed along it course it can be compressed most favourably in the middle of the arm, where the artery lies on the tendon of the coracobrachialis. The biceps can be made prominent by flexing the elbow. ${ }^{19}$

Cadaveric Study- Dissection of the cadaver for the purpose to see superficial vessels, we followed the Cunningham's Mannual of practical anatomy.

\section{Upper Limb-}

- First of all, we place the cadaver in supine position and made midline incision from the jugular notch to the xiphisternal junction.

- We made an incision from the jugular notch along the clavicle to the acromion and then from the xiphisternal junction to the anterior axillary fold (left the nipple surrounding skin in position as a landmark). Continued this incision down the lateral side of the arm to a point that is approximately halfway down the arm.

- Then made an incision begins from halfway anteriorly of the arm to the tip of the middle finger.

- While dissecting the cadaver for the purpose to observe superficial vessels the upper limb, there was no need to open the pectoral region totally.

- The flaps of skin and superficial fascia were reflected laterally by blunt dissection.

- The deep fascia was divided in the deltopectoral groove to uncover the cephalic vein.

- The cephalic vein was followed through the upper part of the clavipectoral fascia to the axillary vein.

- Coracobrachialis and short head of biceps muscle were exposed. And then the axillary artery and median nerve were founded out medial to these muscles.

- Medial to the axillary artery, the axillary vein was identified with the medial cutaneous nerve of the forearm between them and posterior to that the larger ulnar nerve.

- In the arm the brachial artery was found superficial and was covered by the layers of skin, as well as the superficial and deep fasciae, except in the cubital fossa (where the bicipital aponeurosis, covers the artery) and near the distal attachment of coracobrachialis, where the median nerve crosses the brachial artery.

- We saw the brachial artery in the lower half of the upper arm, lateral to the median nerve as the nerve crosses the brachial artery from lateral to medial side.

- The radial nerve on the posterior aspect of the artery before it enters the radial groove was seen.

\section{DISCUSSION}

Acharya Sushruta may be indirectly saying that the Jaladhara Sira is situated superficially since he has used the word Abhyantar for Lohitaksha and Urvi Sira next to Jaladhara. 
Urvi Sira is present in lower extremity and its counterpart in upper extremity is named as Bahavi. Urvi (Bahavi) is an Avedhya Sira as well as Sira marma and is situated in the middle of the arm. Injury to this Marma causes atrophy or wasting of muscles of the arm from the loss of blood and blood loss may lead to death. It is a Vaikalyakar type of marma.

So, the site of Urvi (Bahavi) marma can be considered as site for Bahavi Sira.

In the upper extremity, brachial artery and profunda brachi artery was found in this site. Brachial artery is a continuation of axillary artery and axillary artery is continuation of subclavian artery, it is directly connected to arch of aorta then attached to heart. Thus, due to direct connection with heart, velocity of blood is increase, so any puncturing or venesection of these vessels may cause severe blood loss. Brachial artery supplies the brachioradialis, supinator and brachialis muscles. Therefore, due to loss of blood by puncturing the brachial artery, it may cause wasting or atrophy of the muscles of arm. Therefore, brachial artery and profunda brachy artery can be considered as Avedhya Sira. Results of trauma to Bahavi Marma and puncture of Urvi Sira are almost similar; hence, we can establish a relationship between them.

\section{CONCLUSION}

- Sira is one of the important components of Marma, according to the definition of Marma. So Avedhya Sira and Sira Marma have definite relationship.

- Urvi (Bahavi) Avedhya Sira and Bahavi Sira Marma have almost same structural involvements.

- The sign and symptoms occurring after injury to both Urvi Sira and Urvi Marma are almost similar. i.e., deformity or death.

- In the upper extremity Urvi (Bahavi) Sira can be correlated with brachial artery and profunda brachy artery.

\section{REFERENCES}

1. Sushrut Samhita (illustrated) Vol. 1, - English translation, Shrikantha Murthy K.R; Published by Chaukhamba Orientalia, Varanasi, $2^{\text {nd }}$ Edition, 2004-Sharir Sthan chapter 6/14, Page no.- 107.

2. Sushrut Samhita (illustrated) Vol. 1, - English translation, Shrikantha Murthy K.R; Published by Chaukhamba Orientalia, Varanasi, ${ }^{\text {nd }}$ Edition, 2004-Sharir Sthan chapter 6/3, Page no.- 103.

3. Charak Samhita, Chaukhambha Bharati Academy, Reprint year 2016, Sutra Sthana Chapter 30/12, Page no.584.

4. Sushrut Samhita (illustrated) Vol. 1, - English translation, Shrikantha Murthy K.R; Published by Chaukhamba Orientalia, Varanasi, $2^{\text {nd }}$ Edition, 2004, Sharir Sthan chapter 7/3, Page no.- 122.

5. Sushrut Samhita (illustrated) Vol. 1, - English translation, Shrikantha Murthy K.R; Published by Chaukhamba Orientalia, Varanasi, $2^{\text {nd }}$ Edition, 2004, Sharir Sthan chapter 7/19, Page no.- 125.

6. Sushrut Samhita (illustrated) Vol. 1, - English translation, Shrikantha Murthy K.R; Published by Chaukhamba Orientalia, Varanasi, $2^{\text {nd }}$ Edition, 2004, Sharir Sthan, chapter 6/24, Page no.- 110.

7. Sushrut Samhita (illustrated) Vol. 1, - English translation, Shrikantha Murthy K.R; Published by Chaukhamba Orientalia, Varanasi, $2^{\text {nd }}$ Edition, 2004, Sharir Sthan chapter 6/7, Page no.- 105.

8. Sushrut Samhita (illustrated) Vol. 1, - English translation, Shrikantha Murthy K.R; Published by Chaukhamba Orientalia, Varanasi, $2^{\text {nd }}$ Edition, 2004, Sharir Sthan chapter 6/12-13, Page no.- 106.

9. Sushrut Samhita (illustrated) Vol. 1, - English translation, Shrikantha Murthy K.R; Published by Chaukhamba Orientalia, Varanasi, $2^{\text {nd }}$ Edition, 2004, Sharir Sthan chapter 6/6, Page no.- 104.

10. Sushrut Samhita (illustrated) Vol. 1, - English translation, Shrikantha Murthy K.R; Published by Chaukhamba Orientalia, Varanasi, $2^{\text {nd }}$ Edition, 2004, Sharir Sthan chapter 6/28, Page no.- 116.

11. Ashtang Hridyam of Vagbhata, Edited with the Vidyotini Hindi Commentary by Kaviraj Atrideva Gupta, Chaukhamba Prakashan, Reprint 2016, Sharir Sthan 4/60, Page no.-271

12. Ashtang Hridyam of Vagbhata, Edited with the Vidyotini Hindi Commentary by Kaviraj Atrideva Gupta, Chaukhamba Prakashan, Reprint 2016, Sharir Sthan 4/7, Page no.-265. 
13. A Sanskrit- English Dictionary, Sir M. Monier- Williams, Published by Bharatiya Granth Niketan, Edition 2007, Page no.-218.

14. Sushrut Samhita (illustrated) Vol. 1, - English translation, Shrikantha Murthy K.R; Published by Chaukhamba Orientalia, Varanasi, $2^{\text {nd }}$ Edition, 2004, Sharir Sthan chapter 7/22, Page no.- 127.

15. Sushrut Samhita of Sushruta with the Nibandhasangraha Commentary of Shri Dalhanacharya, Chaukhamba Sanskrit Sansthan Varanasi Edition reprint 2019, Sharir Sthan 6/6, page no.- 370.

16. Sushrut Samhita, Sharir Sthanam, hindi commentary by Dr. Bhaskar Govind Ghanekar, Published by Meharchand Lachhmandas Publication Reprint January 2017, Vaktavya, Page No.- 210.

17. Gray's Anatomy the Anatomical basis of Clinical Practice, Susan Standring Thirty- ninth Edition Section 5, Chapter 50, Page No.- 856.

18. Gray's Anatomy the Anatomical basis of Clinical Practice, Susan Standring Thirty- ninth Edition Section 5, Chapter 50, Page No.- 857.

19. Surface and radiological anatomy with a clinical perspective, by Ashwini C Appaji and Roopa Kulkarni, the health sciences publisher, Reprint 2017, page No.-70.

\section{Source of Support: Nil \\ Conflict of Interest: None Declared}

How to cite this URL: Microsoft Word - Comparative Study of Avedhya Sira and Sira Marma with special reference to Urvi Sira. International Ayurvedic Medical Journal \{online\} $2020 \quad$ cited May, 2020\} Available from: http://www.iamj.in/posts/images/upload/2348_2352.pdf 